\title{
Five Kingdoms, and Talking Beasts: Some Old Greek Variants in Relation to Daniel's Four Kingdoms
}

\author{
Ian Young
}

\section{Different Directions in Hebrew Bible Textual Criticism}

Textual criticism of the Hebrew Bible has often been conceived as having a narrow focus on evaluating variant readings in order to establish the earlier, or in fact, the original text of the Bible. However, current mainstream scholarship on the textual history of the Hebrew Bible has abandoned the claim that we are in a position to arrive at the original text of the Bible. For example, the standard handbook by Emanuel Tov states that "the textual evidence does not point to a single 'original' text, but a series of subsequent authoritative texts produced by the same or different authors ... the original text is far removed and can never be reconstructed." 1

This does not mean that scholars have abandoned the quest to evaluate variant readings and to attempt to build a case for whether readings are earlier or later. But it means that they are much more aware that establishing what is an earlier reading is not necessarily the same thing as discovering the original reading. Study of the evidence has further demonstrated that a high percentage of variant readings are not due to "errors" as was common language in many older approaches to textual criticism. Instead, it is accepted that variants were often created intentionally, due to the different conception of books held in those ancient cultures. ${ }^{2}$ First, evidence suggests that for ancient people, an "exact" copy of a text did not usually involve what we would describe as word for word accuracy, as long as what was understood to be the essential message was conveyed. This makes the concept of an original text even more problematic, since this mindset would not lead to even two contemporary "original"

1 Emanuel Tov, Textual Criticism of the Hebrew Bible, 3rd ed. (Minneapolis: Fortress Press, 2012), 167-68.

2 On what follows, see especially the work of Raymond F. Person, Jr., The Deuteronomic History and the Book of Chronicles Scribal Works in an Oral World, AIL 6 (Atlanta: SBL Press, 2010), 41-68; Raymond F. Person, Jr., "Text Criticism as a Lens for Understanding the Transmission of Ancient Texts in Their Oral Environments," in Contextualizing Israel's Sacred Writings: Ancient Literacy, Orality, and Literary Production, ed. Brian B. Schmidt, AIL 22 (Atlanta: SBL Press, 2015), 197-215, with references to his other publications. See also Ian Young, "The Dead Sea Scrolls and the Bible: The View from Qumran Samuel," ABR 62 (2014): 14-30. 
copies of the same text being exactly alike. Second, as community literature, the books of the Hebrew Bible had a complex relationship with a larger oral tradition which dealt with the subjects in the written text. This interaction could lead to variant forms of the same story, psalm, etc., coming into written form, ${ }^{3}$ or lead to the common observation that ancient texts tend to grow over time, with the addition of extra material from the tradition finding itself included in written form. ${ }^{4}$

Greater awareness of the nature of ancient literature has led to a greater appreciation of the breadth of the textual tradition of each of the biblical books. If ancient compositions were by nature fluid, then the definition of a biblical book as "the original text" is impractical and probably misleading. Instead, a biblical composition like the Book of Daniel can be understood as the sum of the various different manuscripts that we happen to have, bearing in mind that there were likely a significant number of other different manuscripts in antiquity, now lost to us. This way of viewing a biblical book invites us to value all of the variant forms of the book and to use them as a way of discussing the broader tradition of the Book of Daniel.

In view of these considerations, recent scholarship has begun to see textual variants as important for other reasons than just as potential evidence of an earlier text or, indeed, the original text of a book. ${ }^{5}$ Textual critics are not just engaged in the business of sieving through the myriads of variants in the hope of discovering the one small gold nugget of the earliest recoverable text. They should, instead, be thought of as historians of the textual development of the biblical books. They can, for example, ask such important questions as how readers of these variant manuscripts might have understood the text of the Bible that they knew. Because the fact of the matter is, many or most ancient people, such as the New Testament writers, were actually reading these texts, not some scholarly reconstruction of an original text. In this case, textual

3 For example, the highly variant forms of Daniel 5. See Ian Young, "The Original Problem: The Old Greek and the Masoretic Text of Daniel Chapter 5," in Empirical Models Challenging Biblical Criticism, ed. Raymond F. Person, Jr. and Robert Rezetko, AIL 25 (Atlanta: SBL Press, 2016), 271-301.

4 See David M. Carr, The Formation of the Hebrew Bible: A New Reconstruction (Oxford: Oxford University Press, 2011), 99: "As a general rule, ancient scribes who were producing a new version of an ancient tradition ... either preserved it unchanged (aside from memory or graphic variants) or expanded it." See also Juha Pakkala, God's Word Omitted: Omissions in the Transmission of the Hebrew Bible, FRLANT 251 (Göttingen: Vandenhoeck \& Ruprecht, 2013), 9o: "It may be indisputable that under many, perhaps under most circumstances the texts mainly developed by way of expansions."

5 See Ronald Hendel, Steps to a New Edition of the Hebrew Bible, TCSt 10 (Atlanta: SBL Press, 2016), 327: "Deliberately composed variants, even if historically secondary, deserve to be objects of study, rather than textual debris consigned to the 'prison house' of the apparatus." 
criticism becomes part of the discussion of the reception history of the biblical books.

By allowing comparison and contrast of the different ways that a text could be constructed, furthermore, the use of variant texts as "comparative commentary" allows readers of all existing texts of a biblical book to see more clearly the ways in which each text constructs its message. By studying the different ways that Daniel texts, for example, are evidenced, the reader gains a clearer insight into the specific characteristics of each of them. One may ask the question of what difference it makes to have a Daniel text that says this rather than that? Another advantage is that witnesses are read for themselves, as well as evidence for possible earlier stages of the text. Thus, a comparative commentary is interested in the witnesses themselves, not just the often extremely complicated questions involved in evaluating potential earlier and later readings, and not only on the one reading judged the earliest one attested.

With these thoughts in mind, I would like to introduce some of the important variants relating to the four kingdoms in Daniel that the Old Greek (OG) text has when compared to the Masoretic Text (Мт) which most readers are much more familiar with.

To simplify, the textual evidence for Daniel falls into two basic classes. On the one hand is the мт and those texts which have a close relationship with it, albeit with occasional significant variants, or a relatively large number of minor variants. This MT-related group includes the eight fragmentary Daniel manuscripts from the Qumran or Dead Sea Scrolls, dating to the second and first centuries $\mathrm{BCE}^{6}{ }^{6}$ as well as the Greek translation of Theodotion, perhaps from the first century BСE, the Syriac Peshitta, commonly dated in the second century ВСE, and the Latin Vulgate from ca. $400 \mathrm{CE} .{ }^{7}$ On the other side to this

6 On accepting the arguments for a first century BCE deposit date for the Qumran scrolls, see Gregory L. Doudna, "Dating the Scroll Deposits of the Qumran Caves: A Question of Evidence," in The Caves of Qumran: Proceedings of the International Conference, Lugano 2014, ed. Marcello Fidanzio, STDJ 118 (Leiden: Brill, 2017), 238-46, with the bibliography cited there.

7 For information on these texts, see Armin Lange, "Ancient Manuscript Evidence," in The Textual History of the Bible: The Hebrew Bible: Volume ${ }_{1} C$ Writings, ed. Armin Lange and Emanuel Tov (Leiden: Brill, 2017), 528-32; D. Amara, "Septuagint," in The Textual History of the Bible: The Hebrew Bible: Volume 1 C Writings, ed. Armin Lange and Emanuel Tov (Leiden: Brill, 2017), 542-54; Richard A. Taylor, "Peshitta," in The Textual History of the Bible: The Hebrew Bible: Volume ${ }_{1} C$ Writings, ed. Armin Lange and Emanuel Tov (Leiden: Brill, 2017), 558-61; Michael Graves, "Vulgate," in The Textual History of the Bible: The Hebrew Bible: Volume ${ }_{1} \mathrm{C}$ Writings, ed. Armin Lange and Emanuel Tov (Leiden: Brill, 2017), 568-71. 
мт group is the fascinatingly variant text of Daniel reflected in another Greek translation, the Old Greek Daniel, usually considered to have been made as early as the second century вСЕ. ${ }^{8}$

We are fortunate to have the Old Greek translation of Daniel at all, since it was almost obliterated from the textual record by Theodotion. In fact there are only two major manuscript witnesses to it in Greek, with a host of minor witnesses to parts of it. These consist of, first of all, one pre-Hexaplaric witness, Papyrus 967, dated to the second or no later than the early-third century CE. ${ }^{9}$ In addition there are two closely related Hexaplaric witnesses, the Greek manuscript 88 (Codex Chisianus, dated to the 9th-11th centuries CE) and the Syro-Hexapla (Codex Ambrosianus, dated to the 8th-9th centuries CE; originally made $616-617 \mathrm{CE}$; henceforth Syh). ${ }^{10}$

It is necessary to stress the problems caused by this limited textual evidence for our knowledge of the shape of the $\mathrm{OG}$ translation as it was originally made and, therefore, also how this original og related to its Vorlage. None of the few manuscripts we possess is a straightforward witness to the OG translation as it was originally made. Thus, although the relatively early Papyrus 967 is usually considered to be a much superior witness to the later 88-Syh, nevertheless, it contains evidence that it has also been corrupted in various ways. Problems of simple scribal error are more difficult to identify with such a slim textual base. Furthermore, all the witnesses to the oG have suffered from corruptions under the influence of the dominant Theodotion (MT) tradition. ${ }^{11}$ Comparison of 967 with 88-Syh shows how often 88-Syh has been influenced by the MT tradition. Given our knowledge of the pressure to conform with the MT tradition, and the dominance of the Theodotion form of text, it seems most likely that when the two texts differ, one being in conformity with the мт/Theodotion, the other divergent with it, that it is the MT-like reading that is secondary.

8 Amara, “Septuagint," 543.

9 For a detailed introduction to papyrus 967 see Joseph Ziegler and Olivier Munnich, Septuaginta: Vetus Testamentum Graecum Auctoritate Academiae Scientiarum Gottingensis editum XVI.2: Susanna Daniel Bel et Draco (Göttingen: Vandenhoeck \& Ruprecht, 1999), 63-76. For recent introductions to the Greek versions of Daniel, see R. Timothy McLay, "Daniel (Old Greek and Theodotion)," in The T\&T Clark Companion to the Septuagint, ed. James K. Aitken, Bloomsbury Companions (London: Bloomsbury T\&T Clark, 2015), 54454; and Amara, "Septuagint."

10 On 88-Syh, see Ziegler and Munnich, Susanna Daniel Bel et Draco, 22-5o.

11 Timothy McLay, The $O G$ and Th Versions of Daniel, scs 43 (Atlanta: Scholars Press, 1996), 14, 109, 214-15, 242; Ziegler and Munnich, Susanna Daniel Bel et Draco, 76; Olivier Munnich, "Texte massorétique et Septante dans le livre de Daniel," in The Earliest Text of The Hebrew Bible: The Relationship Between the Masoretic Text and the Hebrew Base of the Septuagint Reconsidered, ed. Adrian Schenker, scs $5^{2}$ (Atlanta: SBL Press, 2003), 93-120 (esp. 94-95). 
Therefore, the likely direction of corruption seems clear. However, comparison of 967 with 88-Syh and other witnesses also shows that already 967 has been subject to corruption toward the мт/Theodotion. ${ }^{12}$ Our "best" witness for OG Daniel is still far from simply a representation of the translation as it was first made. Nevertheless, it is these manuscripts that ancient readers were actually reading.

The issues with the mixed OG-Theodotion nature of our manuscript witnesses, plus the fact that in a significant number of cases the OG is not a word for word translation of its Vorlage, means that it is quite a challenge to interpret the evidence that OG Daniel provides for its Semitic language Vorlage. Nevertheless, it is well worth attempting to investigate the oG's Vorlage since it is a very interesting variant text of Daniel, one that is definitely under-utilized by Daniel scholars. Furthermore, once we realize that textual criticism is about more than just attempting to work out which of the variant readings is the earliest attested, we can pay attention to all the variant forms of Daniel separate from the quest for a potentially variant Vorlage. From this point of view it does not matter whether we consider the readings as earlier, or as created by processes such as assimilation to the $\mathrm{MT} /$ Theodotion tradition. The focus is on the evidence the manuscripts provide for the broader tradition of the book of Daniel. The OG witnesses evidence an often dramatically different text of Daniel. This is especially the case in chapters 4,5 , and 6 , with, for example, Daniel 5 differing from the $\mathrm{MT}$ in length (it is much shorter), characterization, and key plot elements. ${ }^{13}$ But there are significant variants in every single chapter of oG Daniel; in fact, in almost every single verse. ${ }^{14}$

\section{$3 \quad$ Five Kingdoms in og Daniel 2}

Here is a comparison of the evidence of the major OG manuscripts with the MT in Dan 2:39-41. ${ }^{15}$ There are many interesting variants between the OG and м т but several in Dan 2:39-41 relate to the count of kingdoms. We pick up just

12 See McLay, OG and Th Versions of Daniel, 214-15: "It is also obvious that corruption of og MSs towards Th and MT is not limited to 88 -Syh, but includes 967 , our best representative of og."

13 See the two texts set out in parallel in Young, "The Original Problem," 273-83.

14 See Ian Young, "What is Old Greek Daniel Chapter 8 About?" JsoT 44 (2020): 693-710 on Daniel 8 as having a quite different storyline in the oG compared to the MT.

15 The translation of the Greek is based on Timothy McLay, "Daniel," in A New English Translation of the Septuagint, ed. Albert Pietersma and Benjamin G. Wright (Oxford: Oxford University Press, 2007), 991-1022, with occasional adjustments to more clearly indicate certain features of the OG text in comparison with the MT. The translation of the MT is mine, with the aim of facilitating comparison of the texts. 
after the moment that Daniel has identified the head of gold of the statue in the vision that King Nebuchadnezzar saw as Nebuchadnezzar and his kingdom. The numbers in the og Ziegler Munnich column give the numbers of the kingdoms in the $\mathrm{OG}$, showing that we come to five. In contrast, the numbering of the third and fourth kingdoms in the MT leaves no doubt that we are talking about only four kingdoms.

\section{og Ziegler Munnich ${ }^{16}$}

39. And after (1) you will rise (2) a kingdom smaller than yours ...

OG: $x \alpha \grave{l} \mu \varepsilon \tau \dot{\alpha} \sigma \varepsilon \dot{\varepsilon} \sigma \tau \dot{\eta} \sigma \varepsilon \tau \alpha l$

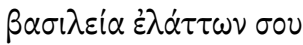
... and (3) another kingdom of bronze, which will rule over the whole earth,...

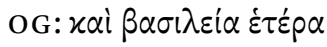

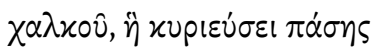

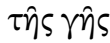

40. .... and (4) another kingdom, strong as iron,...

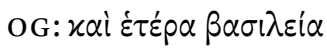

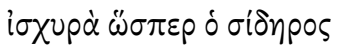

... which saws everything and cuts down every tree, ...

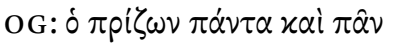

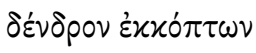

MT

And after you will arise another kingdom, inferior to you ...

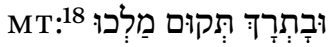

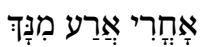

... and another, third

kingdom of bronze

which will rule over all the earth.

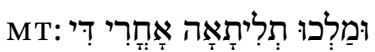

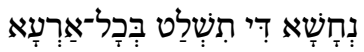

And there will be a fourth kingdom, strong as iron ...

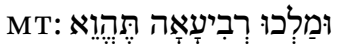

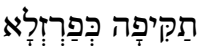

... because iron crushes and shatters everything ...

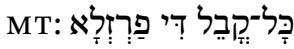

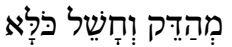

\section{Variants $^{17}$}

MT + another $(=967$ $[\alpha \lambda \eta\rceil])$.

MT + third $(=967$, 88-Syh $\left.\left[\tau \operatorname{pi}^{\prime} \eta \hat{\beta} \alpha \sigma i \lambda \varepsilon i \alpha\right]\right)$. og (967): Another // MT: fourth (=88-Syh).
OG: which // MT:

because iron. OG (967): saws everything // og (88-Syh): overpowers $(\delta \alpha \mu \dot{\alpha} \zeta \omega \nu)$ everything // MT: crushes. OG: Cuts down every tree // MT: shatters.

16 The critical text of Ziegler and Munnich, Susanna Daniel Bel et Draco. We note the complexity of the textual evidence provided by the witnesses to the oG in the variants column and below.

17 All variants from the MT are noted here, as well as significant inner-Greek variants that will be discussed below.

18 Where the MT contains a Qere/Ketiv variant, only the Qere is presented here, since none of them are relevant to the current discussion. 

... and the whole earth will
be shaken.

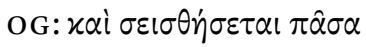 $\dot{\eta} \gamma \hat{\eta}$

41. And as you saw its feet partly of iron and partly of potter's ware:...

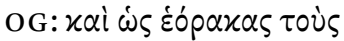

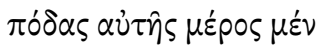

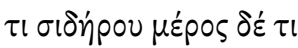

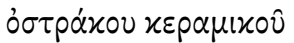

... there will be (5) another, divided kingdom,...

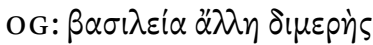
हैं $\tau \alpha$ l

... and some of the iron base (root) will be in it;...

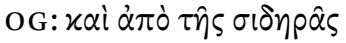

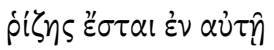

... just as you saw the iron commixed with the clay ware,...

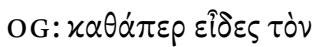

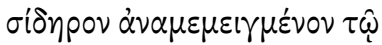
$\pi \eta \lambda i v \omega$ o $\sigma \tau \rho \alpha \dot{\alpha} x \omega$
... and like iron which

Totally variant. ${ }^{19}$

smashes it will crush

and smash all these.

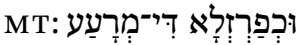

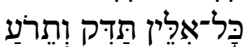

And as you saw the feet and toes were partly of potters' clay and partly of iron ...

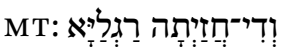

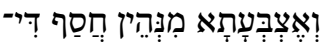

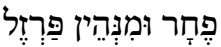

... it will be a divided kingdom ...

MT: מַלְכוּ פְלִיגָה תֶתהַוה

... but some of the

88: all minus

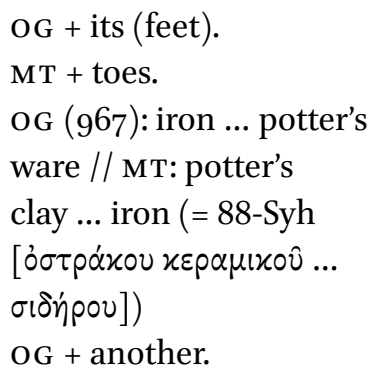

firmness of iron will be in it ...

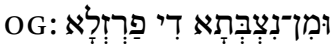

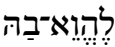

... because as you saw iron is mixed with the miry clay.

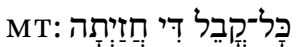

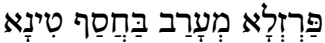

The мт has a series of kingdoms, with the last two clearly numbered three and four. The description of the fourth kingdom is quite complex (carrying on for two more verses after the segment presented above), leading to suggestions of later reworking. Comparison with the lack of "toes" in the oG in verses $41 \mathrm{a}$ and

19 The relationship between the versions is actually more complex here than this presentation would imply, but that discussion is beyond our interest here. For example, it is sug-

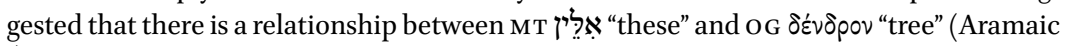
(אילָ) of the previous clause, see R. H. Charles, A Critical and Exegetical Commentary on the Book of Daniel (Oxford: Clarendon, 1929), 48; John J. Collins, A Commentary on the Book of Daniel, Hermeneia (Minneapolis: Fortress Press, 1993), 151 n. 101. 
42a has, for example, led to a widespread belief that they are a later addition to the MT. ${ }^{20}$

Our interest here, however, is on a major variant that is less often noted. This is the fact that the OG seems to have five kingdoms. Kingdom 1, in verse 39, is the Babylonian King Nebuchadnezzar, designated as "you." Also in verse 39 we have kingdom 2, signified as "will rise a kingdom smaller than yours," then kingdom 3, "another kingdom of bronze." Then, in verse 40, we have kingdom 4 , "another kingdom, strong as iron." These four kingdoms correspond to the four kingdoms of the мт, but a noteworthy point that we will return to about the $\mathrm{OG}$, is the question of the lack of numbering of these kingdoms. The major difference in the count comes in verse 41 . Here, the MT continues talking about its fourth kingdom: "And as you saw the feet and toes were partly of potters' clay and partly of iron, it will be a divided kingdom." However, the oG here brings in its fifth kingdom, stating: "And as you saw its feet partly of iron and partly of potter's ware: there will be another kingdom in two parts."

As is usual with the witnesses to the oG the textual evidence is more complex than a casual perusal of the Göttingen critical text or the NETS translation based on it would suggest. We have already mentioned that one of the major issues in the transmission of the OG was the constant pressure to conform the text to the MT tradition most often reflected in the dominant Theodotion text of Daniel. This affects the text of the passages relevant to the current discussion in a couple of ways. The Göttingen critical text's reading for the fourth kingdom in verse 40, "another kingdom, strong as iron," is based on Papyrus $967 .{ }^{21}$ The other major Greek witness, manuscript 88, reads instead "a fourth kingdom, strong as iron." ${ }^{22}$ Since this reading conforms to the MT/Theodotion ( $\beta \alpha \sigma i \lambda \varepsilon^{\prime} \alpha$ $\tau \varepsilon \tau \dot{\alpha} \rho \tau \eta)$, it is reasonable to suggest that it is a later development of the oG text, to bring it more in line with this tradition. As discussed above, however, the decision that this reading is secondary should not be the last that is said about it. It is still important to ask the question what those real life readers who read this actual manuscript would have made out of this version of the text. In fact,

20 See Louis F. Hartman and Alexander A. Di Lella, The Book of Daniel: A New Translation with Notes and Commentary, AB 23 (Garden City, NY: Doubleday, 1978), 141, 148-49; Michael Segal, Dreams, Riddles, and Visions: Textual, Contextual, and Intertextual Approaches to the Book of Daniel, BZAW 455 (Berlin: Walter de Gruyter, 2016), 52 n. 65.

21 Winfried Hamm, Der Septuaginta-Text des Buches Daniel Kap. 1-2 nach dem Kölner Teil des Papyrus 967, PTA 10 (Bonn: Rudolf Habelt, 1969), 255, also considers that 967 is likely to reflect the original og text.

22 So too the citation by Victorinus of Pettau in his commentary on Revelation "quartum autem regnum." See the tabulation of the various witnesses to this phrase in Hamm, Der Septuaginta-Text des Buches Daniel Kap. 1-2, 253. 
it seems likely that the numbering of the fourth kingdom would have made even more obvious the fact that the "another kingdom" of the following verse must be a plus one to kingdom four, meaning a fifth kingdom.

A similar, but more acute, textual problem is posed by the third kingdom in verse 39. Here both 967 and 88-Syh read, like мт, "and another, third kingdom"

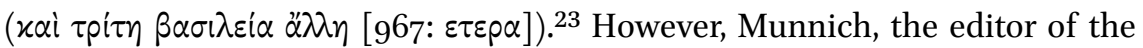
critical text, has conjectured that even though attested by all of our (few) witnesses, it too is due to the influence of the мт/Theodotion tradition. ${ }^{24}$ This leads to a text that is consistent in introducing each of kingdoms three, four and five as "another kingdom," without any of them being numbered. ${ }^{25}$ If he is right, and the logic is reasonable, we have further evidence of the influence that the MT's four kingdom schema, with its numbered kingdoms, had on the development of the oG text.

The oG text reaches five kingdoms by having two final kingdoms (before the kingdom of God) rather than the one of the мт. The distinction made would be between Alexander's original kingdom, "strong as iron, which saws everything and cuts down every tree, and the whole earth will be shaken," and what follows. This is a good picture of the irresistible nature of Alexander's conquest, for which see also Dan 8:5-7. Just as in Dan 8:8, the vision goes on to describe the break-up of Alexander's kingdom by talking of the divided nature of the kingdom in the phrase "there will be another kingdom in two parts." Given the early date of the oG text, these two kingdoms would presumably be intended to be the Ptolemaic and Seleucid, and the OG is making clear that these were different kingdoms to Alexander's, with their own characteristics. ${ }^{26}$

When discussing the kingdoms of Daniel chapter 2, scholars routinely talk about the four kingdoms of the MT, and the obvious connection with Daniel 7 is made, with its four kingdoms. It is commonly pictured that the influence ran from Daniel 2, an earlier text, to Daniel 7, which drew on the picture of the four

23 Cf. Victorinus who has "tertium regnum," not reflecting "another" (cf., Theodotion, mentioned below). See the tabulation of the witnesses in Hamm, Der Septuaginta-Text des Buches Daniel Kap. 1-2, 253.

24 Ziegler and Munnich, Susanna Daniel Bel et Draco, 86, 254. Note that Theodotion varies from the мт here in having only "a third kingdom" without "another." In contrast to Munnich, Hamm (Der Septuaginta-Text des Buches Daniel Kap. 1-2, 253) suggests that 967 probably reflects the genuine oG text.

25 Cf. kingdom 2 in the MT and in 967 "another kingdom." Ziegler and Munnich (Susanna Daniel Bel et Draco, 254) follow 88-Syh with "a kingdom smaller than yours" (NETs transla-

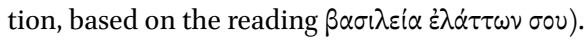

26 So already G. Jahn, Das Buch Daniel nach der Septuaginta hergestellt: Übersetzt und kritisch erklärt (Leipzig: Pfeiffer, 1904), 23: "Nach LXX is das geteilte Reich ein anderes als das Alexanders, entsprechend der Geschichte." 
kingdoms in Daniel 2 to create its own picture. ${ }^{27}$ However, another scenario could conceivably explain the relationship between these two chapters, one that runs the other way, from Daniel 7 to Daniel 2. Although such connections are a feature of the oG as well, it seems to be an especial feature of the M $\mathrm{T}$ that it is a more edited, more finished text than the OG, making more connections between different chapters. An obvious and well accepted example is how MT Dan 5:18-22, minus in the OG, summarizes the story of Daniel 4 to help draw these two chapters even closer together ${ }^{28}$ An alternate scenario for the text history of Daniel 2 and 7 , therefore, is that originally Daniel 2 did not clearly reflect the four kingdom scheme of Daniel 7. It was only subsequently, under the influence of the later chapter, that Daniel 2 was re-edited as in the MT, in order to arrive at a clear, numbered sequence of four kingdoms. ${ }^{29}$ According to this theory, the earlier text, better preserved by the oG, simply followed the

27 See standard references like Collins, Daniel, 294-99, esp. 294: "there is continuity, which indicates that the author of chap. 7 deliberately connected his vision with the older tales. The most obvious points of continuity are with the four-kingdom schema of chap. 2..." See also Carol A. Newsom with Brennan W. Breed, Daniel: A Commentary, ot L (Louisville: Westminster John Knox, 2014), 218: "Obviously, the author of Dan 7 draws explicitly on the schema from ch. 2 of four Gentile kingdoms succeeded by a fifth kingdom that manifests divine sovereignty." James A. Montgomery (A Critical and Exegetical Commentary on the Book of Daniel, ICC [Edinburgh: T\&T Clark, 1927], 175) is one of the few scholars who attempts to account for the oG's five kingdoms while holding to the theory that the four kingdoms schema is original in Daniel 2. He suggests (if I understand his brief note correctly) that it arose due to the fact that "another" was omitted in oG by accident in verse 39 , and that a marginal note to that effect was accidentally incorporated into verse 41 . This is a more complicated theory than the one suggested below, but of course, not impossible.

28 See Collins, Daniel, 242. Some other possible examples suggested by scholars include: the failure of the Babylonian wise men and the introduction of Daniel in мт Dan 4:3-6, minus in OG, as a way of bringing this chapter more in line with Daniel 2 and 5 (e.g., Collins, Daniel, 220); the two tasks of reading and interpreting the writing on the wall in мт Daniel 5 against the one task of rendering the interpretation in OG to conform the story more closely with Daniel 2 (tell the dream and the interpretation) (e.g., Munnich, "Le Livre de Daniel," 111-12); and the small horn of мт Dan 8:9 against the oG's strong horn as a way of linking more closely with the small horn of Dan 7:8 (Segal, Dreams, Riddles, and Visions, 212-13 n. 38).

29 For various suggestions about the influence of Daniel 7's four kingdom scheme on the redaction of Daniel 2, see Pablo S. David, "The Composition and Structure of the Book of Daniel: A Synchronic and Diachronic Reading" (PhD diss., Katholieke Universiteit, Leuven, 1991), 123-36; Reinhard G. Kratz, Translatio Imperii: Untersuchungen zu den aramäischen Danielerzählungen und ihrem theologiegeschichtlichen Umfeld, WMANT 63 (Neukirchen-Vluyn: Neukirchner Verlag, 1991), 48-70; cf., Timothy McLay, "The Old Greek Translation of Daniel IV-VI and the Formation of the Book of Daniel," VT 55 (2005): 304-23, esp. 319. These theories are generally based on literary grounds (e.g., the five part nature of the statue in the vision), not on the og text. 
historical sequence of the kingdoms that were of interest, without such a strong interest in a schematization of history as reflected by the four kingdom model. The MT's new edition of Daniel 2 would, therefore, be a very early example of the influence of the four kingdom schema on the understanding of biblical traditions. This alternative model of the textual development of Daniel 2, and the evidence for it provided by the oG text, deserves more attention in scholarship on the development of the idea of the four kingdoms.

\section{$4 \quad$ Different Beasts in Daniel 7}

While the scheme of four beasts in og Daniel 7 is the same as in the MT, the characteristics of the beasts in each text are different. There is a detectable tendency of the OG to increase the human features of the first three beasts, ${ }^{30}$ which makes an even greater contrast with the terrifying fourth beast.

\subsection{The First Beast}

The MT of Dan 7:4 says concerning the first beast: "The first was like a lion and had wings of an eagle. I was watching until its wings were plucked off and it was lifted from the ground and made to stand on two feet like a man and a heart of a man was given to it." This description of the beast already includes several human features. In addition, there is the following OG variant:

MT

... and it was lifted from the ground and made to stand on two feet like a man ...

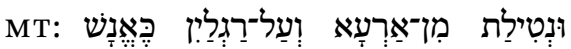
הִִָּימַת
$\mathbf{O G}^{31}$

... and it was lifted from the ground and was set upon human feet ...

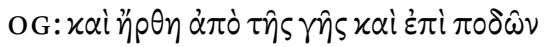
$\dot{\alpha} \nu \theta \rho \omega \pi i v \omega \nu \dot{\varepsilon} \sigma \tau \dot{\alpha} \theta \eta$

Rather than the MT's "made to stand on two feet like a man," the oG simply states that the beast was made to stand on human feet. This wording strengthens the statement in this verse about how the beast is "humanized." They are actually human feet, not just like them.

$30 \quad$ As noted already by T. J. Meadowcroft, Aramaic Daniel and Greek Daniel: A Literary Comparison, JSOTSup 198 (Sheffield: Sheffield Academic Press, 1995), 221.

31 The og here is again the critical text of Ziegler and Munnich, Susanna Daniel Bel et Draco. OG variants are only noted when they are directly relevant to the current discussion. 


\subsection{The Second Beast}

The мт describes the second beast as follows: "And behold another beast, a second one, like a bear. It was raised up on one side and it had three ribs in its mouth between its teeth. And thus they said (it was said) to it: 'Arise and eat much flesh!"' The og includes the following interesting variant:

MT

And thus they said (it was said) to it: "Arise and eat much flesh!"

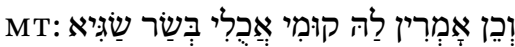

OG

And thus it said, "Rise, devour much flesh!"

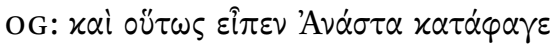

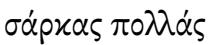

Against the MT, where the beast is addressed, and told to attack, the oG has the beast itself speaking, which adds a human trait to it. Even so, the beast is pictured as being even more aggressive of its own nature, as it seems to be rousing itself up to attack and eat its victims. In the $\mathrm{MT}$, only the fourth beast and the one like a human are depicted as the subject of active verbs. The oG lacks the dimension of divine authorization which seems to be implied by the beast being addressed and told to eat much flesh. Instead, its actions are portrayed as due to human-like deliberation and choice, not mere animal instinct.

\subsection{The Third Beast}

The MT says of the third beast: "After this I looked and behold another, like a leopard, and it had four wings of a bird upon its sides and the beast had four heads and authority was given to it." The oG has the interesting variant:

MT

... and authority ... and language was given was given to it. to it.

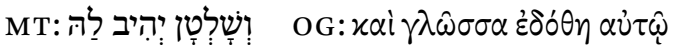

\section{Variants}

MT: authority// og (967, Syh): language// 88 minus of "and language was given to it"

The OG, as represented by 967 and Syh, reads instead of the MT's "authority"

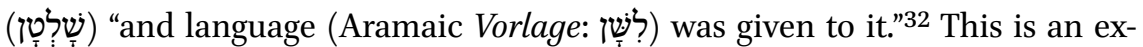
ample where there is a graphical similarity between variants in the мт and the

32 The objection of Sharon Pace Jeansonne (The Old Greek Translation of Daniel 7-12, СвQMS 19 [Washington: Catholic Biblical Association of America, 1988], 119) that a tongue could also belong to an animal, and that it does not necessarily indicate speech is weakened by the fact that in Daniel "tongue" always refers to language. See Dan 1:4, the "language" of the Chaldeans and the repeated "peoples, nations and languages" in Dan 3:4, 7, 29 (singular), 31; 5:19; 6:26; 7:14. 
Vorlage of the OG, here involving metathesis of the first two letters and the MT having an extra tet. Pace Jeansonne declares this to be a "simple metathesis," ${ }^{33}$ but it seems a rather complicated error, involving not only metathesis, but also an additional letter in the MT. ${ }^{34}$ Thus it seems better to take it as some sort of conscious substitution of terms, albeit perhaps influenced by some sort of verbal play of similar sounds. This could be due to the OG translator, his Vorlage, or by the мт tradition. In favor of the secondary nature of the MT might be that, on consideration, it is strange that it is mentioned that this beast is granted authority. Presumably all the beasts have authority, since they all represent kingdoms. Scholars explain the MT's explicit mention of "authority" as due to making a link with the dream in chapter 2 where it is said that the third kingdom "shall rule over all the earth" (Dan 2:39), and hence the authority of the third beast is explicitly noted in this chapter. ${ }^{35}$ The MT reading could then be explained as another case of it secondarily making closer links between chapters.

Even if we decide that the oG reading is secondary, it is important to remember that it was this text, not another, that was read by many readers of Daniel in the ancient world. Thus, Beale considers the OG reading to lie behind Rev 13:5, where the beast from the sea, an amalgam of the beasts of Daniel 7 ,

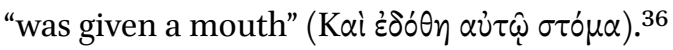

Against these other witnesses, OG manuscript 88 has a minus of this phrase "and language was given to it." This is considered to have been left out by error, and is present in Syh as well as $967 .^{37}$ This is not the end of the discussion, however, since this secondary reading was present in at least this one text, and one may ask the question what a reader of this text would have made of it. In contrast to the other texts of Daniel 7, in 88 neither language nor authority is given to this beast. It is simply a beast. The third beast gets very little space in this chapter in every witness. The absence of these distinguishing features in 88 would have made it pass even more quickly in the succession of kingdoms leading to the terrible fourth kingdom.

33 Pace Jeansonne, The Old Greek Translation of Daniel 7-12, 119.

34 Meadowcroft (Aramaic Daniel and Greek Daniel, 221 n. 61) points out that no evidence is provided of another similar case of metathesis.

35 See Montgomery, Daniel, 29o; Collins, Daniel, 298; and Newsom, Daniel, 224.

36 G. K. Beale, "A Reconsideration of the Text of Daniel in the Apocalypse," Bib 67 (1986): 539-43 (esp. 542). For the beast in Revelation 13 as an amalgam of the four beasts in Daniel 7, see G. K. Beale, The Book of Revelation: A Commentary on the Greek Text, NIGTC (Grand Rapids: Eerdmans, 1999), 685.

37 Angelo Geissen, Der Septuaginta-Text des Buches Daniel, Kap. 5-12, zusammen mit Susanna, Bel et Draco, sowie Esther, Kap. 1, 1a-2, 15 nach dem Kölner Teil des Papyrus 967, PTA 5 (Bonn: Habelt, 1968), 37, 101. 


\subsection{The Fourth Beast}

There is no trace of humanization in either the MT or the OG in the description of the fourth beast which is, in the MT, described as "a fourth beast, dreadful and fearful and exceedingly strong. And it had great teeth of iron; it devoured and crushed and the remains it stamped with its feet. And it was different to all the beasts who were before it and it had ten horns." The one important variant to mention in the oG is that instead of "it was different to all the beasts," the oG

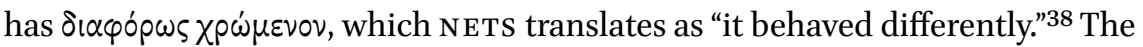
MT seems to emphasize the essentially different nature of the fourth beast, while the og seems to focus on the way the beast acts. For the oG, it is yet another beast, not in essence different to the others, yet it does not behave in the same manner as those that have gone before. ${ }^{39}$

The positive aspects of divine authorization or humanization in the MT are taken to create a greater contrast with the fourth beast. ${ }^{40}$ In the oG, all the first three beasts have human characteristics. The og reflects a text where the first three beasts share this similarity to each other, and this highlights the contrast with the completely inhuman fourth beast more sharply. Nevertheless, the first three beasts are not said to be essentially different to the fourth beast. In contrast, in the MT, the beasts are more bestial, especially after the first one, and yet the fourth beast is even of a different nature to them. This is a good example where comparing the different texts helps brings out the particular emphases of each.

\section{5}

Conclusion

In these case studies, we have demonstrated that taking the oG text of Daniel into account has several benefits for the scholar of the Daniel tradition. First, the oG can evidence earlier stages in the composition of the book of Daniel than the MT. However, beyond the possibility of discovering an earlier reading than the MT, which is what has commonly been the focus in textual criticism, consideration of OG variants, whether they are judged earlier or later than the MT, or simply that they represent parallel developments of the Daniel tradition, has further benefits. Thus, second, the oG variants provide further evidence of the way the Daniel tradition developed in antiquity. Third, by

38 See T. Muraoka, A Greek-English Lexicon of the Septuagint (Leuven: Peeters, 20o9), 735, §II, $1 \mathrm{c}$.

39 Cf. Meadowcroft, Aramaic Daniel and Greek Daniel, 221.

40 Newsom, Daniel, 223. 
providing an example of a different way that a Daniel text can be presented, they lead us to see more clearly the specific emphases of each text. Fourth, these alternative texts of Daniel were actually the ones used by ancient readers of Daniel, and thus we can attempt to understand what they conveyed to these earlier readers of the book, the ones who continued to value and develop the idea of the four kingdoms.

\section{Bibliography}

Amara, D. "Septuagint." Pages 542-54 in The Textual History of the Bible: The Hebrew Bible: Volume $1 C$ Writings. Edited by Armin Lange and Emanuel Tov. Leiden: Brill, 2017.

Beale, G. K. "A Reconsideration of the Text of Daniel in the Apocalypse." Bib 67 (1986): 539-43.

Beale, G. K. The Book of Revelation: A Commentary on the Greek Text. NIGTC. Grand Rapids: Eerdmans, 1999.

Carr, David M. The Formation of the Hebrew Bible: A New Reconstruction. Oxford: Oxford University Press, 2011.

Charles, R. H. A Critical and Exegetical Commentary on the Book of Daniel. Oxford: Clarendon, 1929.

Collins, John J. A Commentary on the Book of Daniel. Hermeneia. Minneapolis: Fortress Press, 1993.

David, Pablo S. "The Composition and Structure of the Book of Daniel: A Synchronic and Diachronic Reading." PhD diss., Katholieke Universiteit, Leuven, 1991.

Doudna, Gregory L. "Dating the Scroll Deposits of the Qumran Caves: A Question of Evidence." Pages 238-46 in The Caves of Qumran: Proceedings of the International Conference, Lugano 2014. Edited by Marcello Fidanzio. STDJ 118. Leiden: Brill, 2017.

Geissen, Angelo. Der Septuaginta-Text des Buches Daniel, Kap. 5-12, zusammen mit Susanna, Bel et Draco, sowie Esther, Kap. 1, 1a-2, 15 nach dem Kölner Teil des Papyrus 967. PTA 5. Bonn: Habelt, 1968.

Graves, Michael. "Vulgate." Pages 568-71 in The Textual History of the Bible: The Hebrew Bible: Volume ${ }_{1} C$ Writings. Edited by Armin Lange and Emanuel Tov. Leiden: Brill, 2017.

Hamm, Winfried. Der Septuaginta-Text des Buches Daniel Kap. 1-2 nach dem Kölner Teil des Papyrus 967. PTA 10. Bonn: Rudolf Habelt, 1969.

Hartman, Louis F. and Alexander A. Di Lella. The Book of Daniel: A New Translation with Notes and Commentary. АВ 23. Garden City, NY: Doubleday, 1978.

Hendel, Ronald. Steps to a New Edition of the Hebrew Bible. TCSt 10. Atlanta: SBL Press, 2016. 
Jahn, G. Das Buch Daniel nach der Septuaginta hergestellt: Übersetzt und kritisch erklärt. Leipzig: Pfeiffer, 1904.

Kratz, Reinhard G. Translatio Imperii: Untersuchungen zu den aramäischen Danielerzählungen und ihrem theologiegeschichtlichen Umfeld. WMANT 63. NeukirchenVluyn: Neukirchner Verlag, 1991.

Lange, Armin. "Ancient Manuscript Evidence." Pages 528-32 in The Textual History of the Bible: The Hebrew Bible: Volume ${ }_{1} C$ Writings. Edited by Armin Lange and Emanuel Tov. Leiden: Brill, 2017.

McLay, Timothy. The og and Th Versions of Daniel. scs 43. Atlanta: Scholars Press, 1996. McLay, Timothy. "The Old Greek Translation of Daniel IV-VI and the Formation of the Book of Daniel." VT 55 (2005): 304-23.

McLay, Timothy. "Daniel." Pages 991-1022 in A New English Translation of the Septuagint. Edited by Albert Pietersma and Benjamin G. Wright. Oxford: Oxford University Press, 2007.

McLay, Timothy. "Daniel (Old Greek and Theodotion)." Pages 544-54 in The T\&T Clark Companion to the Septuagint. Edited by James K. Aitken. Bloomsbury Companions. London: Bloomsbury T\&T Clark, 2015.

Meadowcroft, T. J. Aramaic Daniel and Greek Daniel: A Literary Comparison. JSOTSup 198. Sheffield: Sheffield Academic Press, 1995.

Montgomery, James A. A Critical and Exegetical Commentary on the Book of Daniel. ICc. Edinburgh: T\&T Clark, 1927.

Munnich, Olivier. “Texte massorétique et Septante dans le livre de Daniel." Pages 93120 in The Earliest Text Of The Hebrew Bible: The Relationship Between the Masoretic Text and the Hebrew Base of the Septuagint Reconsidered. Edited by Adrian Schenker. scs 52. Atlanta: SBL Press, 2003.

Muraoka, T. A Greek-English Lexicon of the Septuagint. Leuven: Peeters, 2009.

Newsom, Carol A. with Brennan W. Breed. Daniel: A Commentary. ot L. Louisville: Westminster John Knox, 2014.

Pace Jeansonne, Sharon. The Old Greek Translation of Daniel 7-12. СвQMS 19. Washington: Catholic Biblical Association of America, 1988.

Pakkala, Juha. God's Word Omitted: Omissions in the Transmission of the Hebrew Bible. FRLANT 251. Göttingen: Vandenhoeck \& Ruprecht, 2013.

Person, Jr., Raymond F. The Deuteronomic History and the Book of Chronicles Scribal Works in an Oral World. AIL 6. Atlanta: sBL Press, 2010.

Person, Jr., Raymond F. "Text Criticism as a Lens for Understanding the Transmission of Ancient Texts in Their Oral Environments." Pages 197-215 in Contextualizing Israel's Sacred Writings: Ancient Literacy, Orality, and Literary Production. Edited by Brian B. Schmidt. AIL 22. Atlanta: SB L Press, 2015.

Segal, Michael. Dreams, Riddles, and Visions: Textual, Contextual, and Intertextual Approaches to the Book of Daniel. BZAW 455. Berlin: Walter de Gruyter, 2016. 
Taylor, Richard A. "Peshitta." Pages 558-61 in The Textual History of the Bible: The Hebrew Bible: Volume 1 C Writings. Edited by Armin Lange and Emanuel Tov. Leiden: Brill, 2017.

Tov, Emanuel. Textual Criticism of the Hebrew Bible. 3rd ed. Minneapolis: Fortress Press, 2012.

Young, Ian. "The Dead Sea Scrolls and the Bible: The View from Qumran Samuel." ABR 62 (2014): 14-3o.

Young, Ian. "The Original Problem: The Old Greek and the Masoretic Text of Daniel Chapter 5." Pages 271-301 in Empirical Models Challenging Biblical Criticism. Edited by Raymond F. Person, Jr. and Robert Rezetko. AIL 25. Atlanta: SB L Press, 2016.

Young, Ian. "What is Old Greek Daniel Chapter 8 About?" JSOT 44 (2020): 693-710.

Ziegler, Joseph and Olivier Munnich. Septuaginta: Vetus Testamentum Graecum Auctoritate Academiae Scientiarum Gottingensis editum XVI.2: Susanna Daniel Bel et Draco. Göttingen: Vandenhoeck \& Ruprecht, 1999. 